\title{
Environmental and geochemical record of human- induced changes in $C$ storage during the last millennium in a temperate wetland (Las Tablas de Daimiel National Park, central Spain)
}

Fernando Domìnguez-Castro, Juan Ignacio Santisteban, Rosa Mediavilla, Walter E. Dean, Enrique Lípez-Pamo, María Joségil-García \& María Blanca Ruiz-Zapata

To cite this article: Fernando Domìnguez-Castro, Juan Ignacio Santisteban, Rosa Mediavilla, Walter E. Dean, Enrique Lípez-Pamo, María Joségil-García \& María Blanca Ruiz-Zapata (2006) Environmental and geochemical record of human-induced changes in $\mathrm{C}$ storage during the last millennium in a temperate wetland (Las Tablas de Daimiel National Park, central Spain), Tellus B: Chemical and Physical Meteorology, 58:5, 573-585, DOI: 10.1111/j.1600-0889.2006.00211.x

To link to this article: https://doi.org/10.1111/j.1600-0889.2006.00211.x

ใ (c) 2006 The Author(s). Published by Taylor \& Francis.

Submit your article to this journal $₫$

View related articles 주
曲 Published online: 18 Jan 2017.

山 Article views: 60

Citing articles: 17 View citing articles $\asymp$ 


\title{
Environmental and geochemical record of human-induced changes in $\mathrm{C}$ storage during the last millennium in a temperate wetland (Las Tablas de Daimiel National Park, central Spain)
}

\author{
FERNANDO DOMÍNGUEZ-CASTRO ${ }^{1 *}$, JUAN IGNACIO SANTISTEBAN ${ }^{2}$, \\ ROSA MEDIAVILLA ${ }^{1}$, WALTER E. DEAN ${ }^{3}$, ENRIQUE LÓPEZ-PAMO ${ }^{4}$, \\ MARÍA JOSÉ GIL-GARCÍA ${ }^{5}$ and MARÍA BLANCA RUIZ-ZAPATA ${ }^{5}$, ${ }^{1}$ Dirección de Geología y \\ Geofísica, Instituto Geológico y Minero de España, c/ Calera 1, 28760 Tres Cantos, Madrid, Spain; ${ }^{2}$ Dpt. \\ Estratigrafía, Fac. Ciencias Geológicas, Univ. Complutense de Madrid, 28040 Madrid, Spain; ${ }^{3}$ Earth Surface \\ Processes, United States Geological Survey, Box 25046, MS 980, Federal Center, Denver, CO 80225, USA; ${ }^{4}$ Dirección \\ de Recursos Minerales, Riesgos Geológicos y Geoambiente, Instituto Geológico y Minero de España, c/ Ríos Rosas, \\ 23, 28003 Madrid, Spain; ${ }^{5}$ Dpt.Geología, Univ. Alcalá, N-II, km. 33,600, 28871 Alcalá de Henares, Madrid, Spain
}

(Manuscript received 14 January 2006; in final form 26 June 2006)

\begin{abstract}
Las Tablas de Daimiel National Park has experienced many hydrological and ecological modifications through out its history, both of natural as well as anthropogenic origin, which have affected its carbon storage capacity and carbon fluxes. The study of those variations has been carried out by the analysis of its sedimentary record (geochemistry and pollen) and historical data. The natural changes have a wider variation range than the anthropogenic ones, show repetitive patterns and the system reacts readjusting the equilibrium among its components. Anthropogenic effects depend on the direct or indirect impact on the wetlands of change and its intensity. In addition, the anthropogenic impacts have the capacity of breaking the natural balance of the ecosystem and the internal interactions.
\end{abstract}

\section{Introduction}

One of the main research focuses of the global carbon cycle (C-cycle) is finding the 'missing sink'. Although the uncertainty associated with each of the known sources and sinks is high, so that the missing sink may be the cumulative result of estimation errors, several lines of evidence suggest that it is real and located on land (Scholes et al., 1999). But, where those sinks and their $\mathrm{C}$ budgets are, is still uncertain (Walker and Steffen 1999). The carbon dynamics of the terrestrial biosphere is complex and its detailed understanding is basic because the terrestrial biosphere plays a major role in the global C-cycle. Also, human disturbance of the $\mathrm{C}$-cycle not only alters the climate system, but also directly affects terrestrial metabolism (Canadell et al., 2000). However, it is impossible to understand the terrestrial biosphere as a whole without prior knowledge of the

\footnotetext{
*Corresponding authors.

e-mail: f.domínguez@igme.es

DOI: $10.1111 / \mathrm{j} .1600-0889.2006 .00211 . \mathrm{x}$
}

particular dynamics of each ecosystem integrated in it and how land use changes affect their fluxes through out the different compartments of an ecosystem. The results of these studies are necessary to complete and improve current global C-cycle models.

Research of the C-cycle and human disruption of terrestrial ecosystems has concentrated mainly on a few ecosystems such as peatlands (Moore et al., 1998; Turetsky et al., 2002) and forests (mainly boreal and tropical). Ecosystems such as temperate forests and aquatic-terrestrial environments such as lakes, reservoirs and wetlands, although all of them have important C fluxes (Dean and Gorham, 1998) and are under intense human pressure, have received less attention and are sometimes not included in models that simulate future carbon balances. Another point that is not usually implemented in the models is the possible feedbacks of wetland desiccation, such as soil decomposition (Field et. al., 2004).

Our main goal in this paper is to present and compare the evolution of $\mathrm{C}$ storage in a Mediterranean temperate wetland in response to the modifications that led to the change from 


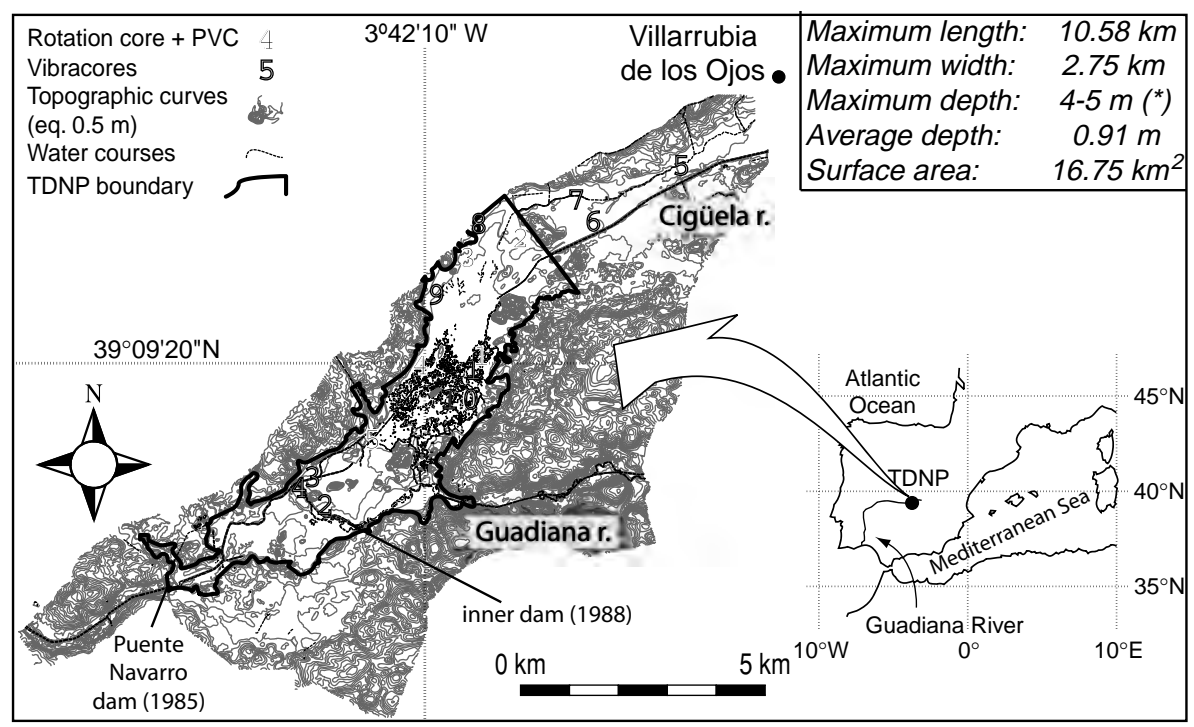

Fig. 1. Studied area, location of core Cigüela 4 and morphological characteristics (from Alvarez-Cobelas et al., 1996) of the wetland basin. $(*)$ : human-modified values due to the presence of dams. Topography, drainage network and TDNP boundary information has been provided by the authorities of the TDNP.

a natural (climate-controlled) system to an intensely modified (human-controlled) one.

\section{Study area}

The Las Tablas de Daimiel National Park (TDNP) is a Mediterranean fluvial wetland located in central Spain (Fig. 1). Until 1983, it was fed by Cigüela (sulphated waters) and Guadiana rivers (carbonated waters) and groundwaters. As result of the combination of these water supplies and the low slope of this area the water flow slowed enough as to allow the development of the wetland with annual renewal of waters (both surface and groundwaters). Since 1983, Cigüela river waters, rainfall and human regulated supplies (from wells and channels) are the only sources of water.

Climate is continental Mediterranean, with an average annual precipitation of $412.6 \mathrm{~mm}$ and annual average temperature of $14.3{ }^{\circ} \mathrm{C}$ (for the 20th century), with dry and hot summers and cold winters. The marked seasonality is responsible of the strong fluctuations actually shown by the water table of the wetland. Before 1980s the situation was very different as the constant flow of groundwater at springs allowed more stable water levels.

The vegetation is dominated by heliophytes, mainly Phragmites australis, Claudium mariscus and Typha domingensis, distributed across the banks and in some patches inside the wetland, at the 'tablas' (open water zones with depth from centimetres up to $4 \mathrm{~m}$ ) appear dense masses of charophytes, and the surrounding areas are dominated by Tamarix, halophytes and crops composed mainly by Vitis, Olea and Cerealia.

\section{Materials and methods}

\subsection{Coring and sediments}

During December 2002 was made a coring campaign, taking 10 rotation cores and 10 manual PVC, to recover the uppermost part intact, in five sites (two per site, covering the different sedimentary environments of the National Park), and 10 vibracores for lithological correlation.

Three representative cores of the present environments of the wetland were selected for geochemical, isotopic, mineralogical, sedimentological and pollen analyses. Of these cores, core Cigüela 4 shows the most complete record and the more evident changes.

Three major facies are represented in this core (Santisteban et al., 2004) and they coincide with present day main environments (Fig. 2). The lowermost materials are gypsum-rich, pale grey to pale green mud facies (clay to very fine clayey sand). Gypsum occurs as disperse lensoidal crystals to the top, but forms centimetric layers of microcrystalline gypsum towards the lower part. This interval shows the lowest contents in organic and inorganic $\mathrm{C}(0.73 \%$ and $1.82 \%$, respectively) and $\mathrm{N}$ of the whole core, low $\mathrm{P}$, high $\mathrm{Al}$, and the highest values in $\mathrm{S}$ (Table 1). This facies represents saline wetland environments characterized by high detrital input and near-surface saline groundwaters.

The following facies is composed by dark grey to black clayrich layers with the highest average content in organic $\mathrm{C}(13.5 \%)$ (Table 1). In addition, this facies shows the highest average content in Al. S shows its lowest mean values while $\mathrm{N}$ and $\mathrm{P}$ suffer a slight increase (Table 1). This facies record macrophyte-rich wetland environments. 


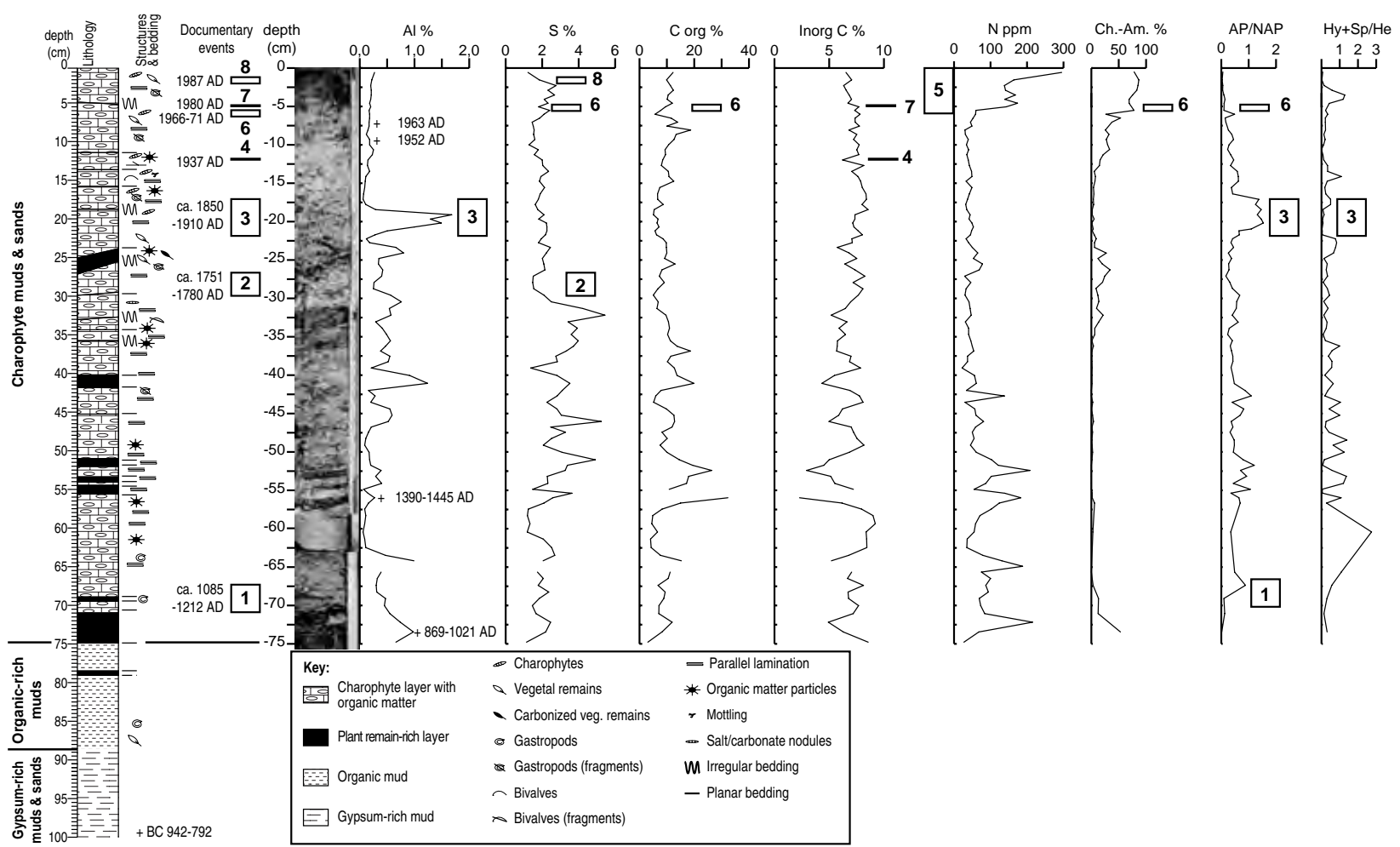

Fig 2. Stratigraphical section of core Cigüela 4 and main geochemical and pollen components with environmental meaning. He: heliophytes; Hy: hydrophytes; Sp: spores; Ch.-Am.: Chenopodiaceae-Amaranthaceae; AP: arboreal pollen; NAP: non-arboreal pollen; Pi: Pinus and eQ: evergreen Quercus. Numbers represent main documentary events (Table 3).

Table 1. Average contents of main geochemical elements of each facies identified in core Cigüela 4

\begin{tabular}{llll}
\hline & $\begin{array}{l}\text { Gypsum-rich } \\
\text { facies }\end{array}$ & Organic-rich facies & $\begin{array}{l}\text { Charophyte } \\
\text { layers }\end{array}$ \\
\hline Inorg. C & $1.82 \%$ & $1.44 \%$ & $6.97 \%$ \\
Org. C & $0.73 \%$ & $13.53 \%$ & $9.77 \%$ \\
Al & $3.85 \%$ & $5.06 \%$ & $0.41 \%$ \\
$\mathbf{S}$ & $8.86 \%$ & $0.88 \%$ & $2.31 \%$ \\
$\mathbf{N}$ & $11 \mathrm{ppm}$ & $17 \mathrm{ppm}$ & $67 \mathrm{ppm}$ \\
$\mathbf{P}$ & $146 \mathrm{ppm}$ & $176 \mathrm{ppm}$ & $197 \mathrm{ppm}$ \\
\hline
\end{tabular}

Lithologically the transition to the upper facies is marked by a neat change from apparently massive dark clays with fragments of gastropods and charophytes to an interbedding of charophyte and vegetal (mainly leaves) layers.

The uppermost deposits, which are the focus of this paper, are charophyte muds and sands of cream colour that, towards the bottom of the interval, alternate with dark green to dark brown vegetal-rich (mainly leaves) laminae. Occasionally, the organic sediment contains high amounts of charcoal. Near the bottom, the organic layers can be tens of millimetres thick, but they always contain carbonated material. The main bioclastic components are fragments of charophyte stems and oogonia, sparse, but well preserved, gastropod shells, and scarce wood fragments. The siliciclastic fraction consists of sand to silt-sized quartz grains. Clay is almost absent. $\mathrm{C}$ content rises to around $17 \%$. Inorganic $\mathrm{C}$ reaches its highest averaged value and organic $\mathrm{C}$ shows the maximum local values. Despite organic $\mathrm{C}$ mean value is lower than for the organic-rich facies, total $\mathrm{C}$ in this zone is a little higher (Table 1). Al shows its minimum values and $\mathrm{S}$ values are low, but not the lowest of the core. $\mathrm{N}$ and $\mathrm{P}$ show their highest mean values but their variation ranges are also the greatest. This facies represents the open wetland environments.

\subsection{Geochemical and pollen analysis}

The core was sampled continuously with an average thickness of $0.7 \mathrm{~cm}$ and for geochemical and pollen analyses in each sample. Samples for geochemistry were analyzed for major, minor and trace elements (ICP-MS and ICP-AES), total $\mathrm{C}$ and $\mathrm{S}$ content (Leco c carbon and sulphur analyser), inorganic $\mathrm{C}\left(\mathrm{CO}_{2}\right.$ coulometry) and organic $\mathrm{C}$ (calculated as the difference between total and inorganic $\mathrm{C}$ ), at ALS Chemex laboratories in Vancouver (Canada), $\mathrm{N}$ was determined as extractable $\mathrm{N}\left(\mathrm{NH}_{4}\right.$, and $\mathrm{NO}_{3}$, colorimetrically) at ALS Environ Labs (Vancouver, Canada). 
Samples for pollen were extracted by flotation on Thoulet's solution (Goeury and Beaulieu, 1979) without acetolysis (Gil García et al., in press). Pollen data are presented as the relative pollen frequency of each taxon.

\subsection{Dating and age model}

AMS ${ }^{14} \mathrm{C}$ dating of samples (four samples) was made at the GADAM Centre (Gliwice, Poland) and ${ }^{239,240} \mathrm{Pu}$ (16 samples) and ${ }^{210} \mathrm{Po}$ (20 samples) at the Centro de Investigaciones Medioambientales (CIEMAT, Madrid, Spain).

Bulk samples were used for AMS dating, as there are no proofs of contamination and all the $\mathrm{C}$ sources are biological (vegetal remains and bioinduced carbonates). Samples were selected according to their stratigraphical position in parts of the core without traces of contamination. For calibration we used CALIB v. 5 (Stuiver and Reimer, 1993; Stuiver et al., 2003) using Reimer et al. (2004) calibration dataset (Table 2).

For ${ }^{210} \mathrm{Po}$ (used to measure the ${ }^{210} \mathrm{~Pb}$ ) and ${ }^{239,240} \mathrm{Pu}$ analyses, the uppermost $15 \mathrm{~cm}$ of a PVC core were used, prepared and measured by high-resolution alpha-spectrometry. The obtained CIC-model rates $\left(0.184 \pm 0.022 \mathrm{~cm} \mathrm{yr}^{-1}\right)$ fitted with the artificial maximum plutonium peak in 1963 and the beginning (estimated in 1952) of its incorporation to the sediment (Fig. 3a). Additionally, the ${ }^{210} \mathrm{~Pb}$ profile confirmed that there was no evident mixing of sediment or hiatuses in the upper part of the core, which coincides with the visual inspection (Fig. 3a).

With all these data, an age-depth model was constructed by linear interpolation of ages between dated samples. The interpolation for the upper $73 \mathrm{~cm}$ (charophyte layers with vegetal remain layers) was extended down to the facies boundary assuming that there were no noticeable changes in the lower $2 \mathrm{~cm}$. For the remaining layers (organic-rich and gypsum-rich muds) a linear interpolation between the boundary interpolated age and a sample inside the gypsum-rich muds ( $0.99 \mathrm{~m}$ in depth) was used, discarding the lowermost dated sample as the age is considered to be too old probably due to contamination. Consequently, for the lowermost layers, the preliminary age model is an average of the two facies (Fig. 3b).

The age model was tested against documented local events (documentary data for the last millennium, Table 3) likely to have been recorded in the sediments. In this sense, we consider a documentary event recorded in the sediments, when an anomalous, sudden or local disruption in the trends or relations among the geochemical or pollen components of the sediments appears, and the interpretation of this 'rupture' is consistent with the effects of a documented event in a chronological position near the interpolated age of the geochemical/pollen anomaly.

The obtained final recalibrated model (Fig. 3b) assumes a $0.184 \mathrm{~cm} \mathrm{yr}^{-1}$ sedimentation rate for the last $100 \mathrm{yr}$.

\section{Climate and human evolution of the last millennium}

\subsection{Regional climate}

Carbon accumulation in wetlands is mostly controlled by the extension of the water table and the biological productivity. Also, the range of the water table fluctuations and length of the hydrological cycle determines the final budget at different timescales.

In the case of the TDNP, the annual cycle of water renewal points to a clear dependence on rainfall (both for surface and groundwaters). Despite the importance of the hydrological cycle, many climate reconstructions for the last millennium focus on the temperature variations of global or hemispheric range (Mann et al., 1998; Moberg et al., 2005). It is recognized that in the longterm such variations are correlated to rainfall trends, but this is not valid for short timescales.

Thus, in order to understand the dynamics of this wetland, we have compared rainfall series from southern Spain (Rodrigo et al., 1999, 2000) and our own data coming from the comparison of instrumental and documentary sources (rogation ceremonies), covering in the two last cases around the last $500 \mathrm{yr}$, with pollen ratios indicative of climatic or hydrological

Table 2. AMS radiocarbon samples raw and calibrated data. Calibration was performed with CALIB v.5 (Stuiver and Reimer, 1993; Stuiver et al., 2003) using calibration data from Reimer et al. (2004)

\begin{tabular}{|c|c|c|c|c|c|c|}
\hline Depth $(\mathrm{m})$ & Sample & Material & Lab. code & ${ }^{14} \mathrm{C}$ yr BP & $\begin{array}{c}95.4 \%(2 \sigma) \\
\text { cal AD/BC (cal BP) age ranges }\end{array}$ & $\begin{array}{l}\text { Relative area under } \\
\text { probability distribution }\end{array}$ \\
\hline 0.56 & $4-2-79$ & Charophyte sand & GdA-308 & $521 \pm 37$ & $\begin{array}{l}\text { 1318-1352 (598-632) } \\
\text { cal AD 1390-1445 (505-560) }\end{array}$ & $\begin{array}{l}0.195 \\
\mathbf{0 . 8 0 5}\end{array}$ \\
\hline 0.73 & $4-2-101$ & Vegetal layer (charophyte layers) & GdA-309 & $1098 \pm 39$ & $\begin{array}{l}832-836(1114-1118) \\
\text { cal AD 869-1021 (929-1081) }\end{array}$ & $\begin{array}{l}0.002 \\
\mathbf{0 . 9 9 8}\end{array}$ \\
\hline 0.99 & $4-2-132$ & Grey mud with gypsum & GdA-306 & $2699 \pm 53$ & $\begin{array}{l}\text { 974-955 (2904-2923) } \\
\text { cal BC 942-792 (2741-2891) }\end{array}$ & $\begin{array}{l}0.030 \\
\mathbf{0 . 9 7 0}\end{array}$ \\
\hline 1.12 & $4-2-141$ & C-poor, gypsum-rich grey mud & GdA-353 & $7700 \pm 50$ & cal BC 6634-6459 (8408-8583) & 1.000 \\
\hline
\end{tabular}


a)

$$
{ }^{210} \mathrm{~Pb}_{\text {total }} \text { activity concentration }\left(\mathrm{Bq} \mathrm{Kg}{ }^{-1}\right) \quad{ }^{239,140} \mathrm{Pu} \text { activity concentration }\left(\mathrm{Bq} \mathrm{Kg}^{-1}\right)
$$
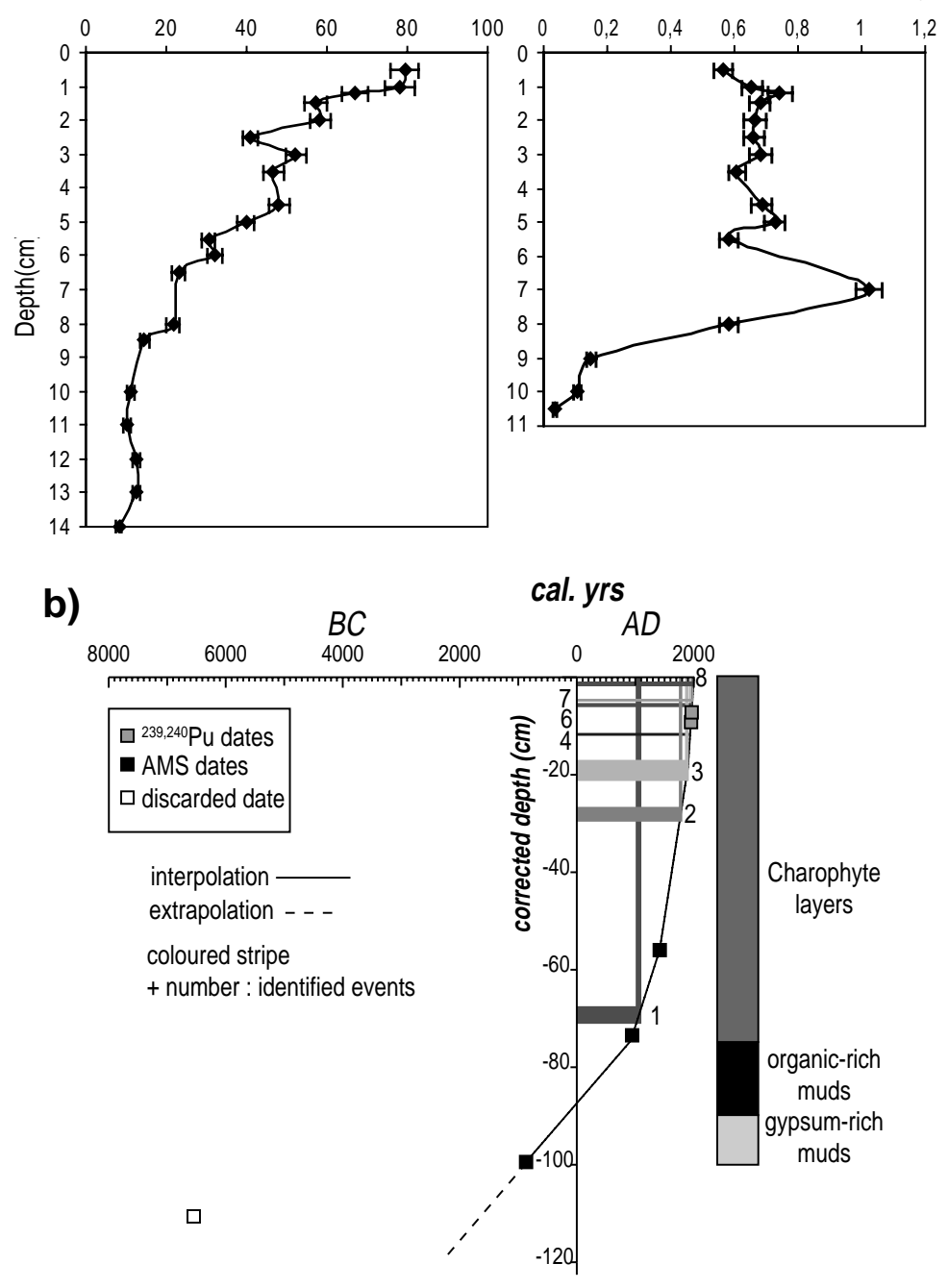

Fig. 3. (a) ${ }^{210} \mathrm{~Pb}$ and ${ }^{239,240} \mathrm{Pu}$ activity concentrations and (b) proposed age-depth model for core Cigüela 4.

ing this period the area was the border between Christians and

conditions (Gil et al., in press), covering the last millennium (Fig. 4).

In the overall, there is good agreement among the reconstructions from documentary and instrumental data of Spain and the pollen interpretation of the record, taking into account the different geographical setting of both areas.

The first recognized climatic period is only recorded in our core and cannot be compared with the other reconstructions. It is characterized a low evergreen Quercus/Pinus (eQ/Pi) ratio, dominance of emergent against submerged vegetation, decreasing values of Chenopodiaceae-Amaranthaceae and increasing values of the arboreal/non-arboreal pollen (AP/NAP). These ratios can be interpreted as cool and relatively dry conditions, but with a trend to wetter conditions, during the 9th and early 10th centuries AD. Such conditions are similar to those described by Desprat et al. (2003) who attribute them to the transition from the Dark Ages to the Medieval Warm Period. However, as dur-
Muslims, it is not possible to discard the influence of man as it has been interpreted by Riera et al. (2004) in NE Spain for this period.

From 11th to 14 th centuries $\mathrm{AD}$, the eQ/Pi ratio, the AP/NAP ratio as well as the hydrophytes and spores against the heliophytic vegetation increase. On the other hand, ChenopodiaceaeAmaranthaceae decreases to recover slightly to the top. These changes record warmer and wetter conditions and an expanding water table but with a trend to more arid conditions in time, identified as typical Mediterranean climate by Dorado et al. (2002). Such conditions are comparable to the Medieval Warm Period as described by Desprat et al. (2003), Juliá et al. (1998) and Riera et al. (2004) for NW and NE Spain.

From the 15th century AD onwards, our record is characterized by highly fluctuating conditions and slightly cooler temperatures. These characteristics suggest that this period represents 
Table 3. Documentary events recorded in the sediments and their duration. For their 'physical' location see Fig. 2.

\begin{tabular}{|c|c|c|c|}
\hline & Event & Year or period & Record \\
\hline \multirow[t]{2}{*}{1} & $\begin{array}{l}\text { Christians conquer Toledo and the Christian-Muslim border } \\
\text { moves to the Guadiana river. }\end{array}$ & $1085 \mathrm{AD}$ & Anomalous AP/NAP ratio (deforestation?). \\
\hline & Continuous battles in the region & $\begin{array}{l}\text { 12th to early } 13 \text { th } \\
\text { centuries }\end{array}$ & \\
\hline \multirow[t]{2}{*}{2} & $\begin{array}{l}\text { Partial draining of the wetland and lowering of the mill dams. } \\
\text { Azuer-Guadiana channel was built to diminish the flooding } \\
\text { of the area but increased freshwater input to the TDNP. }\end{array}$ & $1751-1780 \mathrm{AD}$ & $\begin{array}{l}\text { Decrease in water salinity (sudden drop in S values) as runoff } \\
\text { and Guadiana waters flow improved. }\end{array}$ \\
\hline & Cleaning of water courses. & $1812 \mathrm{AD}$ & \\
\hline 3 & $\begin{array}{l}\text { Mendizabal's and Madoz's land privatization. Changes in the } \\
\text { extension of land pieces. }\end{array}$ & $\begin{array}{l}\text { 2nd half of the } \\
\text { 19th and early } \\
\text { 20th centuries }\end{array}$ & $\begin{array}{l}\text { Al increase (soil erosion) not related to salinity changes ( } \mathrm{S} \text { or } \\
\text { Chenopodiaceae-Amaranthaceae) followed by a sudden drop. } \\
\text { Anomalous AP/NAP and aquatic/emerged vegetation ratios. }\end{array}$ \\
\hline 4 & Demolition of some water mills and wetland desication. & $1937 \mathrm{AD}$ & Local drop of inorganic $\mathrm{C}$. \\
\hline 6 & Draining works inside the wetland, demolition of water mills. & 1966-1971 AD & $\begin{array}{l}\text { Sudden } \mathrm{S} \text { and Chenopodiaceae -Amaranthaceae } \\
\text { increase and AP/NAP and organic C drop. }\end{array}$ \\
\hline 7 & $\begin{array}{l}\text { The natural springs dried out as result of water } \\
\text { overexploitation. }\end{array}$ & $1980 \mathrm{AD}$ & Sudden drop of inorganic $\mathrm{C}$. \\
\hline & Puente Navarro dam was finished. & $1985 \mathrm{AD}$ & \\
\hline 8 & $\begin{array}{l}\text { Artificial water supply starts. } \\
\text { Inner dam is built. }\end{array}$ & $\begin{array}{l}1987 \mathrm{AD} \\
1988 \mathrm{AD}\end{array}$ & Decrease in water salinity (S). \\
\hline
\end{tabular}

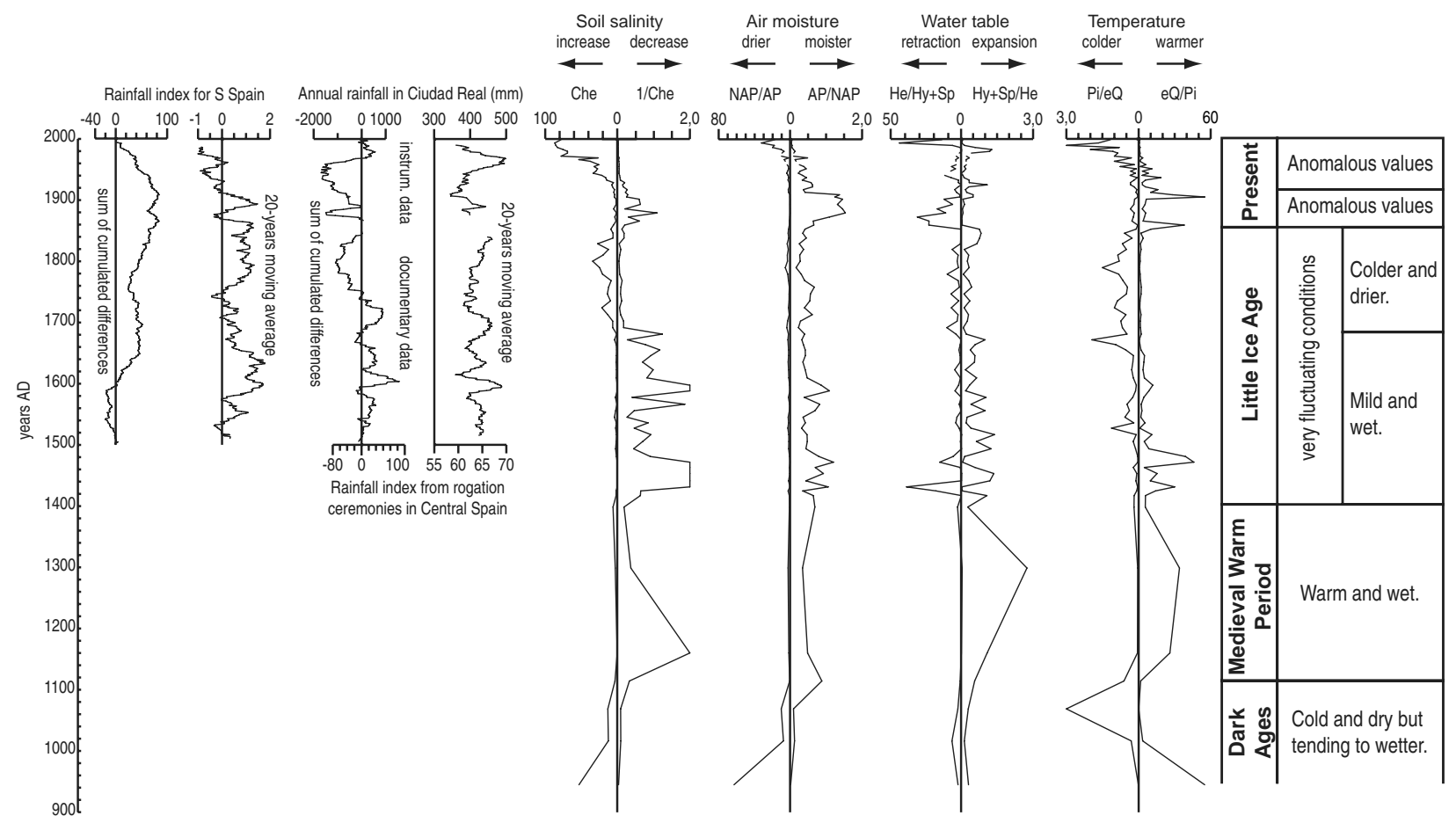

Fig. 4. Regional climatic reconstructions and comparison to the pollen derived climate reconstruction of core 4. Rainfall index data for southern Spain are from Rodrigo et al. (1999, 2000); annual rainfall in Ciudad Real and rainfall index from rogation ceremonies in central Spain data have been compiled by ourselves from data coming from the Meteorological National Institute of Spain (instrumental data) and the Toledo Cathedral archives. For each set of rainfall data we have calculated the sum of cumulated differences and a 20-yr moving average. He: heliophytes; Hy: hydrophytes; Sp: spores; Che: Chenopodiaceae-Amaranthaceae; AP: arboreal pollen; NAP: non-arboreal pollen; Pi: Pinus and eQ: evergreen Quercus. 
the Little Ice Age, also identified by Desprat et al. (2003), Julià et al. (1998) and Riera et al. (2004) in other records in Spain. Three periods can be identified and compared with the complete set of reconstructions.

From 15 th to late 17 th centuries AD the record is characterized by lower, but still representative, eQ/Pi and still high submerged/emergent vegetation ratios and AP/NAP ratio implying a wet and mild climate on the average but with a marked interannual variability. These coincide with the all the rainfall reconstructions that show a trend to more humid conditions with a wetter episode around the beginning of the 17th century AD that is also recorded in the Chenopodiaceae-Amaranthaceae record and in the AP/NAP and submerged/emerged vegetation ratios.

Despite the drop in eQ/Pi ratio around middle 17th century $\mathrm{AD}$, what places the next period (late 17th to middle 19th centuries AD) is the rise in Chenopodiaceae-Amaranthaceae and the expansion of emerged against submerged vegetation to recover the initial conditions from around late 18th century AD onwards. These changes point to drier and colder conditions. These conditions are clearly reflected in our rainfall reconstruction but are less evident in the southern Spain record.

The last period (from middle 19th century onwards) begins with very high and local $\mathrm{eQ} / \mathrm{Pi}$ values and an anomalous rise in the AP/NAP ratio and sudden expansion of the emerged vegetation. After them, there is an increase in ChenopodiaceaeAmaranthaceae, expansion of submerged vegetation and drop in the AP/NAP and eQ/Pi ratios almost until today. These values should be interpreted as a cooling trend until the end of the 20th century and a progressive increase in aridity coeval with expansion of submerged vegetation. These anomalies and the absence of coincidence with the instrumental record points to those values are not reflecting the climate but other factors.

\subsection{Recent human stresses on the wetland}

The historical records reveal that this area has been under relatively low human pressure until two centuries ago when illustrated governments attempted to improve the living conditions of farmers and small towns (Table 3). The first significant transformation (late 18th century) was the attempt of draining the wetland in order to prevent floods and epidemics. To achieve this, main channels were cleaned and an artificial channel was carved to join the Azuer and Guadiana rivers. As a consequence, surface water flow improved and caused an increase in the supply of freshwaters causing a drop in the salinity of the wetland waters (Fig. 2, Table 3).

The following human action with evident consequences for the wetland (middle 19th to early 20th centuries) was a land redistribution (Mendizabal and Madoz's land privatisation) with the aim of increasing land productivity (Fig. 2, Table 3). This led to an increase in the size of the land fields and the abandonment of the traditional alternating cycles of cultivation and non-cultivation and, as a consequence, an increase in ploughing.
However, the most intense change occurred in the second half of the 20th century as introduction of new farming techniques (machinery, pumps, fertilizers, new cultivations, etc.) allowed intensive farming and, therefore, land and water demand increased. Two main human actions impacted the wetland: (1) a desiccation attempt that almost drained the wetland (1965-1971) and (2) a continuous increase in irrigation that caused the water table to drop several meters. As a consequence, the wetland surface decreased by more than $85 \%\left(100 \mathrm{~km}^{2}\right.$ in $1937,60 \mathrm{~km}^{2}$ in 1965 and $15 \mathrm{~km}^{2}$ in 1971) and, now, it only exists by an artificial water supply Those changes leave their imprint in sediments by means of variations in their bulk composition and trends (Figs. 2 and 5).

\section{Discussion}

\subsection{The 'quasi-natural state’}

Until the 18th century, human-wetland interactions were mainly related to the usage of the wetland as a source of energy (water mills), primary products for handcrafts (reed, cattail, etc.), fishing, and hunting. The importance of shepherding and forest ownership was also a factor that determined the equilibrium between human activity and the wetland. Thus, human impacts were of low intensity, and wetland dynamics was mainly governed by natural factors.

Figure 2 shows the main chemical composition interesting elements in core Ciguiela 4 for the last $1100 \mathrm{yr}$ (Al, S, organic and inorganic $\mathrm{C}, \mathrm{N}$ ). The main trends shown in this figure reveal a negative relation between inorganic $\mathrm{C}$ and organic $\mathrm{C}$ and $\mathrm{N}$, and a positive relation between inorganic $\mathrm{C}$ and the (hydrophytes+spores)/heliophytes ratio. But a detailed observation reveals trends or relations of different orders.

(1) Short-scale relations. For the lower half of the core, the increases of $\mathrm{Al}, \mathrm{S}$, organic $\mathrm{C}$ and $\mathrm{N}$ are directly correlated (in position but not necessarily in magnitude) and are reversely related to the inorganic C. This, in turn, can be correlated to the evolution of the submerged/emerged vegetation ratio. For the upper part of the core this relation can be occasionally observed but is partially masked by the drop in the range of their values (Fig. 2). The logical relation of inorganic $\mathrm{C}$ (mostly charophyte stems and oogonia) with the evolution of the aquatic vegetation serves to use this parameter as an indicator of the local water table extent, as the charophytes are light limited and do not expand in areas with emergent vegetation. Consequently, its inverse relation to organic C (mostly derived from vegetal remains -Typha, Cladium and Phragmites leaves) results from their competition for light and it is depth controlled as Typha, Phragmites and Cladium are depth limited (despite they tolerate episodic flooding). Therefore the correlative increment of organic $\mathrm{C}, \mathrm{N}, \mathrm{Al}$ and $\mathrm{S}$ record episodes of low waters and, as it derives from the relation of rainfall with water table extent (Fig. 4), they represent arid 


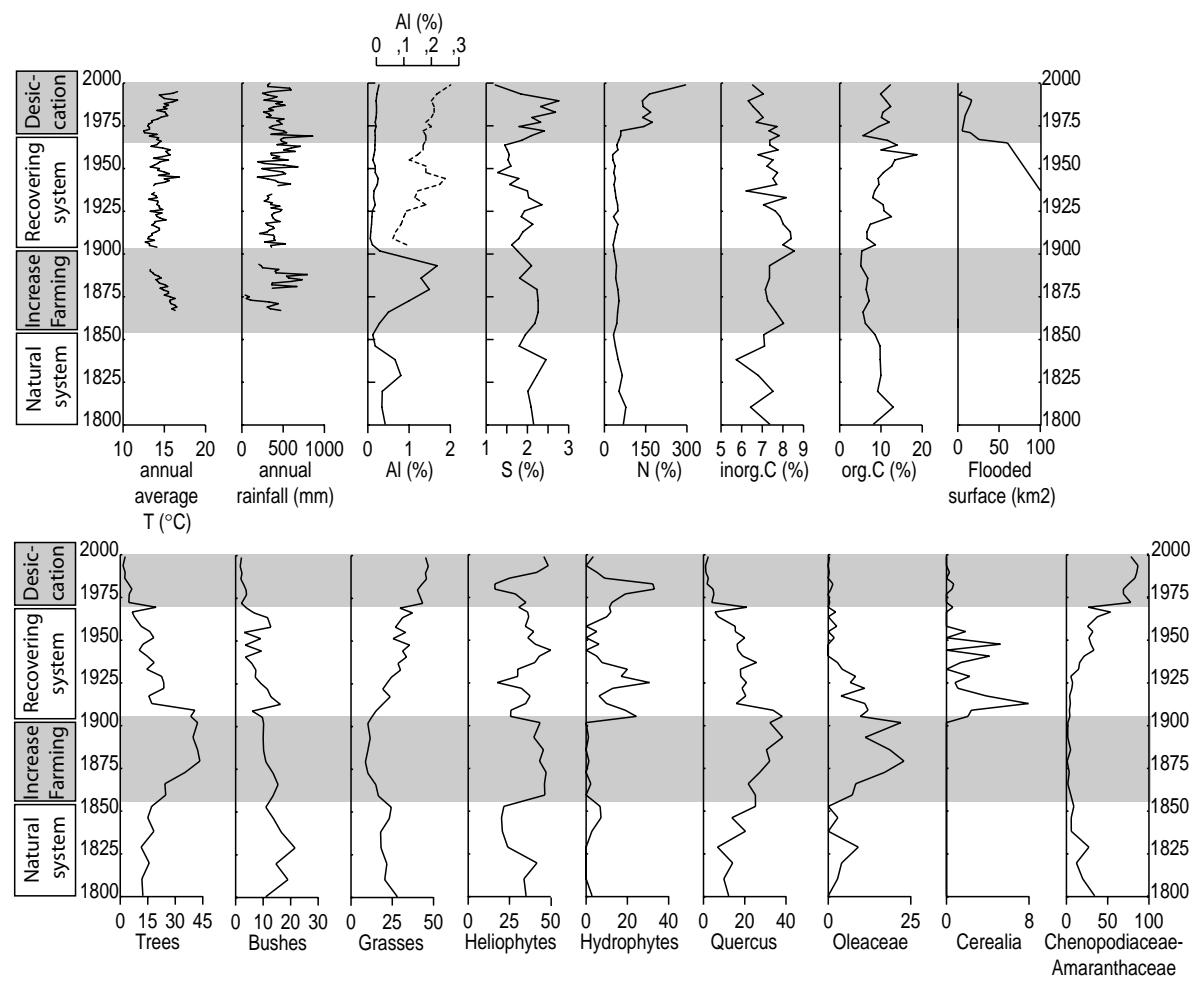

Fig. 5. Annual temperatures and rainfall (Martínez-Santos et al., 2004) and flooded surface for the 20th century. Geochemistry and pollen record for the last $200 \mathrm{yr}$.

periods with gypsum nucleation in the surface and soil degradation (increase in $\mathrm{Al}$ ). These relations reverse during periods of rising water table (wetter). Such trends have been studied in the TDNP by Sánchez-Carrillo et al. (2004) during a 5 yr period.

(2) Long-term trends. On a longer scale the relations among elements change considerably and depend on the climatic period considered. During the Medieval Warm Period (around $55-72 \mathrm{~cm}$ in depth, Fig. 2) the relations are similar to those for the humid short-scale relations, high inorganic $\mathrm{C}$ values related to high submerged/emerged vegetation ratios and moderate to low contents in organic $\mathrm{C}, \mathrm{N}, \mathrm{S}$ and $\mathrm{Al}$ with local excursions. For this period the water table should be in its maximum extent, as it derives from the pollen ratios, and the low variability during this period could be responsible of such sustained values. However, for the first part of the Little Ice Age (from around 32 to $55 \mathrm{~cm}$ in depth, Fig. 2) the values of $\mathrm{S}$ show an increasing trend which is followed by the increase of the background values of inorganic $\mathrm{C}$ while the upper boundary values of the organic $\mathrm{C}$ and $\mathrm{N}$ decrease. On the average, there is also an increase trend in $\mathrm{Al}$, but it is not as evident as for the other elements. For this period, the climate was very fluctuating but conditions were relatively humid and mild. These conditions should have improved faster oscillations of the water table and of greater range which could have conduced to an increase of the number and length of periods of emersion and, in consequence an increase in gyp- sum formation. As salts became preserved in the soil, emergent vegetation had difficulties to develop, while charophytes (living in the aquatic media and more tolerant to salts) increased their representation in percentage.

\subsection{Disturbances of the natural system}

The more obvious change to the top of the sediments is the disappearance of the previous relations among elements and among them and climate (Fig. 2, Fig. 5 upper).

The first evidence of change is observed during the second part of the Little Ice Age (around 23-32 cm in depth, Fig. 2) when the values of $\mathrm{S}$ suddenly fall to their minimum average. This sudden change is not recorded in any other element and, on the other hand, Chenopodiaceae-Amaranthaceae (saline soil taxa) increases noticeably its values. The rest of the elements follow the trend of the previous stage and narrow their range of variation, except for the Al. Additionally, for this period the climate became drier. Such alterations are not consistent with a climate driven change and therefore an alternative explanation must be found. During the second half of the 18th century and up to the beginning of the 19th century, there were many works on the channels feeding the wetland, one of the most important the channel to connect the Azuer river to the Guadiana river that is the present river channel (Table 3), in order to prevent flooding and epidemics. As a result, the surface water supply of 
freshwaters was enhanced but also the residence time of the waters diminished as consequence of the better drainage conditions. Probably, the decrease in S (gypsum formed inside the wetland) records this decrease in water salinity centred in the wetland. In contrast, the increase in Chenopodiaceae-Amaranthaceae, which uses groundwaters and it is a prairie group (external to the wetland), records the drier climatic conditions that promoted the development of saline soils in the surroundings of the wetland.

The following level (around 17-23 cm in depth) is characterized by a sudden and important rise of $\mathrm{Al}$, while the rest of elements remain almost unchanged, and a noticeable increase in the AP/NAP ratio (Fig. 2) coincidental with a decrease in grasses and increases in evergreen Quercus and Oleaceae. ChenopodiaceaeAmaranthaceae almost disappears and, in the aquatic domain, emergent vegetation (heliophytes) spread whereas submerged taxa (hydrophytes) almost disappeared (Fig. 5). Additionally, instrumental records show that this period was relatively wet and, consequently, we cannot argue soil degradation related to arid conditions.

During the second half of the 19th century there were two land privatisation processes ("Desamortizaciones de Madoz y Mendizábal", Table 3) in order to farm (notice the increase in Oleaceae and later increase in Cerealia in Fig. 5 lower) an important extension of land owned by the church, military orders, town councils and the nobility. This led also to a reorganization of land property by concentration of lands (increasing the size of the farming pieces). As a consequence, during a certain period, soil remobilization by ploughing and clearance of lands (grasses removal) increased the amount of siliciclastics reaching the wetland ( $\mathrm{Al}$ increase). This caused the almost disappearance of the submerged vegetation as water turbidity increased and the artificial increase in emerged vegetation.

From 5 to $17 \mathrm{~cm}$ in depth (Fig. 2, early 20th century to $1960 \mathrm{~s}$ in Fig. 5), there is a sudden decrease in $\mathrm{Al}$ together with a recovery of the 'normal' values of the vegetation (Fig. 5 upper). There is an increase in grasses that correlates with the rise in Chenopodiaceae-Amaranthaceae but opposite to the decreasing trend in S. Organic C increases slightly, reversely to inorganic C. Oleaceae is substituted by Cerealia. This record points to a slightly decreasing water table, increasing organic $\mathrm{C}$ against inorganic $\mathrm{C}$ confirmed by the decrease in submerged vegetation towards the top. Water salinity drop (decrease in S) but salinity of soils in the surrounding areas increase (rise in ChenopodiaceaeAmaranthaceae). The sudden decrease in $\mathrm{Al}$ points to a sheltered area, but the increasing values reveal continuous soil erosion. With this constraints the best hypothesis points to a stabilization of farming (cease of land reorganization) and wetland started to recover developing a well vegetated margin that protected it from runoff (drop of $\mathrm{Al}$ ). Increase of irrigation, in number of wells, and the introduction of mechanical pumps caused the slow but progressive lowering of the water table and soil salinization. However, the slightly increasing rainfall during this period
(Fig. 5 upper) caused the progressive freshening of the incoming waters inside the wetland (slow drop in S).

Around the 1960s, there was a new change evidenced by a increase in $\mathrm{S}$ together with a break in the increasing trend of the organic $\mathrm{C}$ and followed later by a decrease in inorganic $\mathrm{C}$ and increase in $\mathrm{N}$ (Fig. 5 upper). In the vegetation, the most evident change was the noticeable increase in ChenopodiaceaeAmaranthaceae together with a decrease in trees and shrubs followed a little later by a decrease in heliophitic (emerged) wetland taxa (Fig. 5 lower).

This was the result of a drop in the water table that corresponds to the desiccation attempt of the 1960s causing salinization both in the wetland and in the surrounding emerged areas. These changes coincide with the sudden drop of the flooded surface of the wetland (Fig. 5, upper). The sustained high values of $S$ are the result of the definitive disconnection of the groundwaters to the surface due to increased water exploitation for irrigation (notice the sudden increase of $\mathrm{N}$ values that are related to the use of fertilizers). The decreasing trend of $S$ in the uppermost part of the record is due to the artificial supply of surface waters, but despite this, salinization of surrounding soils (as recorded by the high values of Chenopodiaceae-Amaranthaceae) became permanent. The decrease of inorganic $\mathrm{C}$ values was noticeable, but organic $\mathrm{C}$ values did not change and as a result the local $\mathrm{C}$ storage rate did not decrease.

\subsection{Qualitative valuation of $C$ budget evolution.}

Until now, we have exposed how the system has reacted to hydrological climate-driven changes and man-induced hydrological and land-use changes for a single location. In first instance, analyzing Fig. 2 it could be said that $\mathrm{C}$ storage has not decreased through time as total $\mathrm{C}$ remains almost constant.

But in order to have an estimate of the 'real' wetland storage variation, it is necessary to analyze spatially the evolution of C-rich facies.

Figure 6 (upper) shows a sketch of the distribution of the main facies of the wetland that is controlled by the morphology of the wetland basin. Its elongated shape, related to its fluvial origin, and the presence of internal islands determines a NE-SW facies pattern with the siliciclastic-rich facies to the NE changing to the inner wetland, protected by islands, where the open waters are encountered (the charophyte-rich 'tablas', shallow and open water bodies). Towards the SW and E, in relation to the GuadianaAzuer rivers, peat was the main deposit as the increased speed of the waters was not favourable for the development of charophyte stands.

The correlation of cores following this facies distribution (Fig. 6, lower) reveals that the maximum thickness of the C-rich facies increases towards the SW (correlation of vibracores 5, 6, cores 2 and 4, vibracore 2 and core PN-1) while in a NW-SE direction the thickness remains almost unchanged (correlation of cores 4 and 1). 


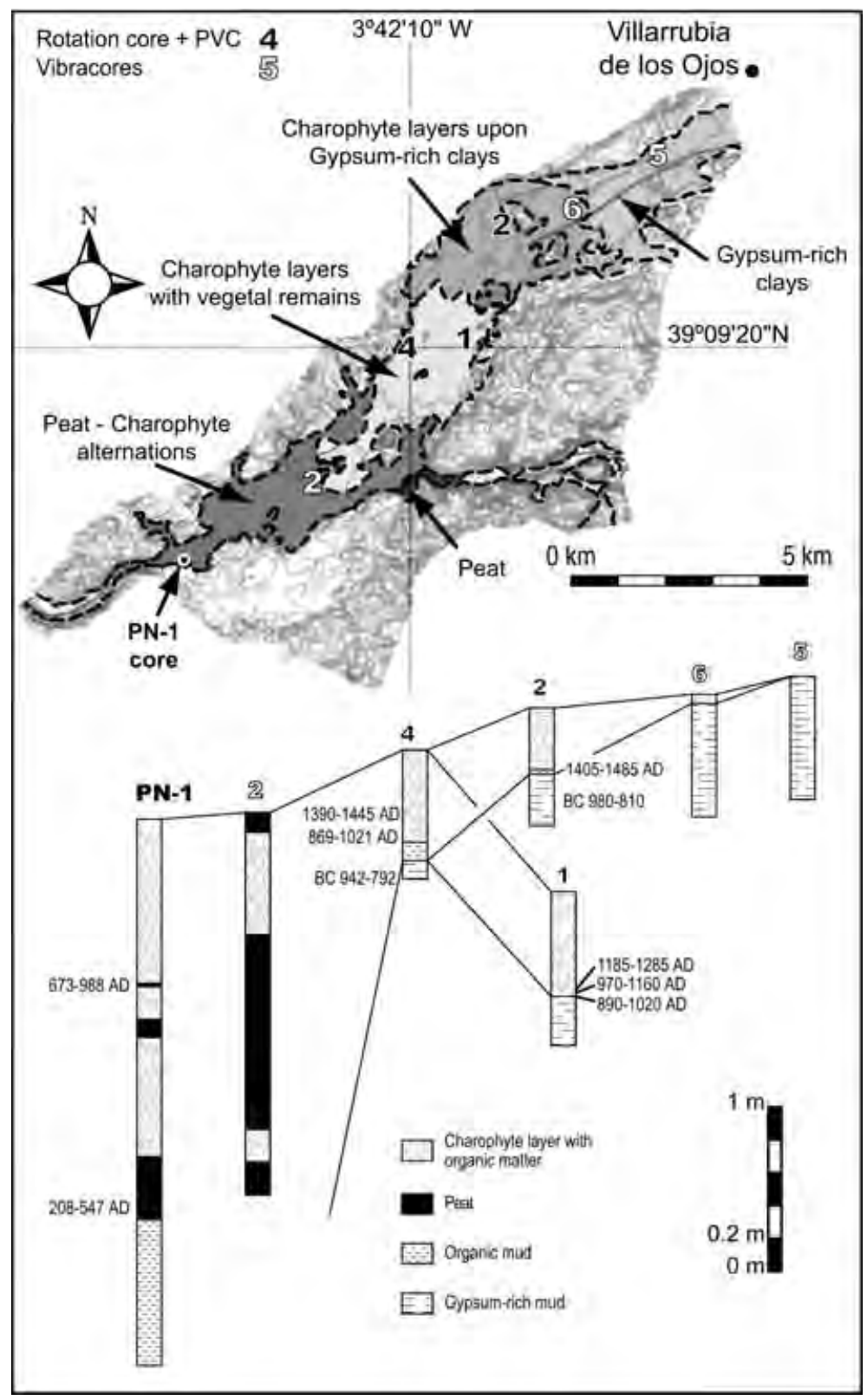

Fig 6. Upper: main lithological (environmental) domains in the TDNP; lower: correlation of cores (calibrated ages) showing the expansive character of the $\mathrm{C}$ producer environments until recent times. Data of core PN-1 are from the Department of Geology of the University of Alcalá (Spain) research project `Analysis of the environmental impact of peat exploitation in the peat bogs related to the Guadiana river in the nearby area to the Llanura Manchega groundwater discharge area and the interest of their preservation'.

Additionally, dates of cores reveal that the C-rich facies have been expanding from SW towards NE for most of the last millennium. Thus, core PN-1 shows more than $3 \mathrm{~m}$ of C-rich facies (charophyte layers, black C-rich clay and peat) with two dated peat levels providing ages from around 3rd to 6th centuries AD (lower) and 7th to 10th centuries AD (upper). Vibracore 2 shows more than $2 \mathrm{~m}$ of C-rich facies (peat and charophyte layers) and cores 4 and 1 show the transition from the low-C facies (gypsum-rich clays) to the C-rich facies to the charophyte-rich layers around the 9 th to 11 th centuries $\mathrm{AD}$. At the following core to the north (core 2), the transition is placed around the 15th century AD. At vibracore 6 the charophyte layers are represented at the uppermost $7.5 \mathrm{~cm}$. Finally, vibracore 5 only shows low-C facies.

Consequently, the C-rich facies have been expanding upstream replacing the low-C bearing clayey facies (gypsum-rich facies) and, consequently, the volume of $\mathrm{C}$ stored in the system has been continuously increasing during most of the last millennium.

This situation changed drastically during the 20th century. In Fig. 7 we can observe the evolution of the wetland under different situation. In 1956, the wetland remained as an open system. No dams closed the flow of waters and these were supplied both by groundwaters and by the Cigüela and Guadiana rivers. The 


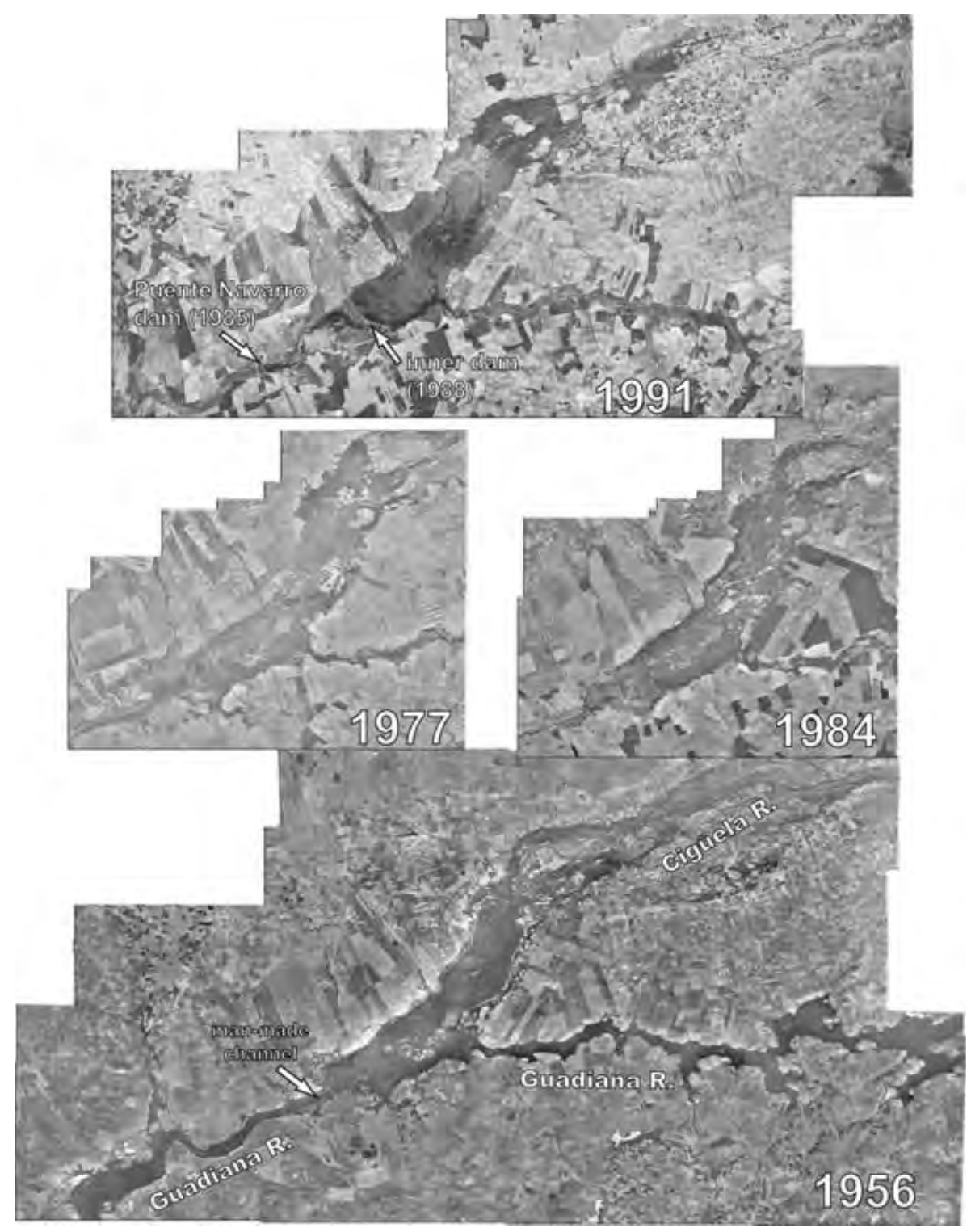

Fig. 7. Aerial orthophotographs of the TDNP corresponding to different periods during the 20th century. 1956: before the draining of the wetland; 1977: after the draining and before the overexploitation of the groundwaters; 1984: after the disconnection of the groundwaters to the surface; 1991: after the construction of the dams and the human regulated supply of water. Orthophotographs have been provided by the TDNP authorities.

Guadiana thalweg was filled by peat deposits both before and after entering the TDNP. Also the Cigüela river was flooded constantly. The 'quasi natural' state of the wetland can be confirmed by the presence of straight reaches of the channels coming from previous attempts of draining the wetland.

After the desiccation works (Fig. 7, 1977) the wetland remained crossed by artificial channels and it is evident the invasion of the Guadiana peat areas by crops. Also, to the north, the Cigüela thalweg is occupied by crops. After the disconnection of groundwaters to the surface the authorities tried to stop the degradation of the wetland by ceasing the canalization works and making the declaration of protected area.
Despite this, in Fig. 7 (1984) is evident that the degradation of the wetland continued. The peat area continued falling both in the channels and in the southern part of the wetland and the flooded areas reduced to the deepest parts of the central area. The apparent recovery of wetland to the north was due to farming abandonment as the soils were too saline to be productive.

In 1985 the Puente Navarro dam was finished as a measure to retain the waters, but despite this, the high evapotranspiration rates and infiltration made this measure insufficient to allow a relatively seasonal water table. As consequence, since the late 1980s, the TDNP is sustained mostly by water supply from the Tagus-Segura channel. In Fig. 7 (1991) it can be seen how the 
dams have allowed the retention of waters and partial restoration of the southern part of the wetland and the. However, it is also evident that the upper reach of the Cigüela and Guadiana rivers have been definitively lost.

This lost implies a change from around $100 \mathrm{~km}^{2}$ of flooded area in 1937 to a maximum flooded area of $18.4 \mathrm{~km}^{2}$ in the period 1979-2006, what means that more than $82.6 \%$ of accumulation surface has been lost (without taking into account the oxidation of peat and its shelf-combustion, relatively frequent in the area).

\section{Conclusions}

The comparison of changes during 'natural' and 'anthropogenic' periods allows the characterization of changes in $\mathrm{C}$ storage in the environment. 'Natural' $\mathrm{C}$ changes show a greater range of variation (Fig. 2) than human-induced changes and they can be directly related to climate fluctuations (Figs. 2 and 4).

But the main difference between natural and human-induced changes is the ability of the system to recover from changes. Climate-driven changes show how the different parts of the system interact among them to sustain a balance both in the short and in the long-term (Fig. 2). On the other hand, land-use and technological human events are short-term and usually sudden changes or events without a clear recovery trend (Fig. 5).

Changes linked to human activity depend on the location (direct or indirect impact) and intensity of the impact. During the land-use changes of the late 19th century, activity was external to the area of the wetland (indirect impact) and its intensity was medium, so the system was able to recover in about $50 \mathrm{yr}$. The wetland was mainly affected by collateral effects of this activity (debris carried to the wetland by runoff), but its internal mechanisms were able to react in some way to recover previous levels of $\mathrm{C}$ storage. In addition, the flooded surface was scarcely affected and, therefore, total $\mathrm{C}$ storage was not substantially modified.

However, draining and water overexploitation in the latter part of the 20th century broke the hydrological balance of the wetland in less than $30 \mathrm{yr}$ and there is still no signal of recovery. Under those circumstances, despite human actions to prevent total desiccation, the loss of the flooded surface and salinization caused a dramatic drop in the volume of stored $\mathrm{C}$ in the system.

In any case, water availability (via temperature/rainfall or water exploitation changes) is the true limiting factor on the equilibrium of this environment and, due to the human demand of water, the role of water availability must be stressed in future projections of the $\mathrm{C}$-cycle on the terrestrial domain.

\section{Acknowledgments}

This research is supported by the Spanish Ministry of Science and Education (MEC) research projects REN2002-04433CO2-01, REN2002-04433-CO2-02 and CGL2005-06458-C0201/HID and F. Dominguez-Castro research is supported by the grant BES-2003-0482 of the Formation of Research Personnel plan of the MEC. We wish to thank to the personnel of the Department of Geology of the University of Alcalá (Spain) integrated in the research project 'Analysis of the environmental impact of peat exploitation in the peat bogs related to the Guadiana river in the nearby area to the Llanura Manchega groundwaters discharge area and the interest of their preservation', funded by the Ramón Areces Foundation, by providing their unpublished data of core PN-1. The authors are very grateful to the staff of the Las Tablas de Daimiel National Park (Spanish Ministry of the Environment) and mainly to its Director D. Manuel Carrasco. The authors are also in debt with Blas Valero-Garcés and an anonymous reviewer for their very valuable comments that have improved the manuscript.

\section{References}

Álvarez Cobelas, M., Verdugo, M. and Cirujano, S. 1996. Geografía y morfometría. In: Las Tablas de Daimiel. Ecología acuática y sociedad (Eds. M. Alvarez Cobelas and S. Cirujano). Publicaciones del Organismo Autónomo Parques Nacionales, Madrid, 23-29.

Canadell, J. G., Mooney, H. A., Baldocchi, D. D., Berry, J. A., Ehleringer, J. R., and co-authors. 2000. Carbon metabolism of the terrestrial biosphere: a multitechnique approach for improved understanding. Ecosystems 3, 115-130.

Dean, W. E. and Gorham, E. 1998. Magnitude and significance of carbon burial in lakes, reservoirs, and peatlands. Geology 26, 535-538.

Desprat, S., Sánchez-Goñi, M. F. and Loutre, M. F. 2003. Revealing climatic variability of the last three millennia in northwestern Iberia using pollen influx data. Earth Planet. Sci. Lett. 213, 63-78.

Dorado-Valiño, M., Valdeolmillos, A., Ruiz-Zapata, M. B., GilGarcía, M. J. and Bustamante, I. 2002. Climatic changes since the Lateglacial/Holocene transition in La Mancha plain (South Central Iberian Peninsula, Spain) and their evidence in The Tablas de Daimiel marshlands. Quatern. Int. 93-94, 73-84.

Field, C. B., Raupach, M. R. and Victoria, R. 2004. The global carbon cycle: integrating humans, climate, and the natural world. In: The Global Carbon Cycle: Integrating Humans, Climate, and the Natural world (Eds. C. B. Field and M. R. Raupach). Island Press. Washinton DC, 1-13.

Gil García, M. J., Ruiz Zapata, M. B., Santisteban J. I., Mediavilla, R., López Pamo, E. and co-authors. Late Holocene environment in Las Tablas de Daimiel (south central Iberian peninsula, Spain). Veg. Hist. Archaeobot.

Goeury, Cl. and Beaulieu, J. L. 1979. A propos de la concentration du pollen à l'aide de la liquer de Thoulet dans les sédiments minéraux. Pollen et Spores 21, 239-251.

Julià, R., Burjachs, F., Dasí, M. J., Mezquita, F., Miracle, M. R., and co-authors. 1998. Meromixis origin and recent trophic evolution in the Spanish mountain lake La Cruz. Aquat. Sci. 60, 279-299.

Mann, M. E., Bradley, R. S. and Hughes, M. K. 1998. Global-scale temperature patterns and climate forcing over the past six centuries. Nature 392, 779-787.

Martínez-Santos, P., Castaño, S., Santisteban, J. I., Martínez-Alfaro, P. E., Mediavilla, R., and co-authors. 2004. Evolución climática durante el último siglo (1904-2002) en el Parque Nacional de Las Tablas de Daimiel (Ciudad Real). Geo-Temas 6 (5), 129-132. 
Moberg, A., Sonechkin, D. M., Holmgren, K., Datsenko, N. M. and Karlén, W. 2005. Highly variable Northern Hemisphere temperatures reconstructed from low- and high-resolution proxy data. Nature $\mathbf{4 3 3}$, 613-617.

Moore, T. R. Roulet, N. T. and Waddington, J. M. 1998. Uncertainty in predicting the effect of climatic change on the carbon cycling of Canadian peatlands. Climatic Change 40, 229-245.

Reimer, P. J., Baillie, M. G. L., Bard, E., Bayliss, A., Beck, J. W., and co-authors. 2004. IntCal04 Terrestrial Radiocarbon Age Calibration, 0-26 Cal kyr BP. Radiocarbon 46, 1029-1058.

Riera, S., Wansard, G. and Julià, R. 2004. 2000-year environmental history of a karstic lake in the Mediterranean Pre-Pyrenees: the Estanya lakes (Spain). Catena 55, 293-324.

Rodrigo, F. S., Esteban-Parra, M. J., Pozo-Vázquez, D. and Castro-Díez, Y. 1999. A 500-year precipitation record in southern Spain. Int. J. Climatol. 19, 1233-1253.

Rodrigo, F. S., Esteban-Parra, M. J., Pozo-Vázquez, F. and CastroDíez, Y. 2000. On the variability of rainfall in southern Spain in decadal to centennial time scales. Int. J. Climatol. 20, 721732.

Sánchez-Carrillo, S., Angeler, D. G., Sánchez-Andrés, R., AlvarezCobelas, M. and Garatuza-Payán, J. 2004. Evapotranspiration in semi-arid wetlands: relationships between inundation and the macrophyte-cover:open-water ratio. Adv. Water Resour. 27, 643655.

Santisteban, J. I., Mediavilla, R.., López-Pamo, E., Dabrio, C. J., Ruiz Zapata, M. B., and co-authors. 2004. Loss on ignition: a qualitative or quantitative method for organic matter and carbonate mineral. $J$. Paleolimnol. 32, 287-299.

Scholes, R. J., Schulze, E. D., Pitelka, L. F. and Hall, D. O. 1999. Biogeochemistry of terrestrial ecosystems. In: The Terestrial Biosphere and Global Change Implications for Natural and Managed Ecosystems (Eds. B. Walker, W. Steffen, L. Canadell and J. Ingram). Cambridge University Press, 271-303.

Stuiver, M. and Reimer, P. J. 1993. Radiocarbon calibration program rev. 3.0.3. Radiocarbon 35, 215-230.

Stuiver, M., Reimer, P. J. and Reimer, R. 2003. CALIB Radiocarbon Calibration, version 4.4. University of Washington Quaternary Isotope Lab (QIL, Available: www.calib.org/).

Turetsky, M., Wieder, K., Halsey, L. and Vitt, D. 2002. Current disturbance and the diminishing peatland carbon sink. Geophys. Res. Lett. 29(No. 11), doi: 10.1029/2001GL014000.

Walker, B. H. and Steffen, W. L. 1999. The nature of global change. In: The Terestrial Biosphere and Global Change Implications for Natural and Managed Ecosystems. (Eds. B. Walker, W. Steffen, L. Canadell and J. Ingram). Cambridge University Press, 1-18. 